\title{
Motivations for Continued Use of Critical Thinking Skills among First-Year Seminar Graduates
}

\begin{abstract}
Many first-year seminar courses, as well as other programs aimed at first-year undergraduate students, actively incorporate critical thinking into the curriculum. What factors motivate students who purposefully develop these critical thinking skills to continue using them during subsequent semesters? This article discusses results of a study on this topic. Twenty-four students participated in a study approximately one semester after completing a first-year seminar at their university. The study uses mixed methods to (a) discuss students' selfreported responses regarding nine potential motivating factors for continuing use of critical thinking skills, (b) examine correlations with critical thinking performance on a writing sample, and (c) briefly compare students' self-reported motivating factors for continued use of critical thinking skills with parallel self-reported motivating factors for continued use of information literacy skills. The article ends with recommendations for applying the findings in the undergraduate classroom.
\end{abstract}

\section{KEYWORDS}

critical thinking, motivation, first-year undergraduate students, educational psychology

\section{INTRODUCTION}

Faculty who teach first-year seminar (FYS) courses to undergraduate college or university students often place significant emphasis on incorporating critical thinking (CT) skills into assignments. For those faculty members, as well as for those who plan FYS and similar courses, one major question is often how to teach these skills in a way that students will retain and choose to continue to use them in other courses. Students' choices to continue the use of those skills supports the effective transfer of learning from the original learning situations to later, related tasks.

The pilot study discussed in this article sheds light on motivating factors that have encouraged first-year undergraduates to continue using CT skills for at least one semester. It was conducted in April and May 2019 at the University of Colorado Denver in Denver, Colorado (USA). Twenty-four students participated in the study, most of whom were "commuter" students, and all of whom completed a FYS course during fall semester 2018 (August-December 2018; approximately one semester before the study). The participants responded to a Likert-style survey exploring nine motivating factors for continued use of CT skills, as well as information literacy (IL) skills. A separate article discusses students' responses on motivating factors for continued use of IL skills. Students also provided some optional free responses on any additional, unanticipated factors that they felt motivated their use of CT skills. This article also correlates the motivating factors with performance on a writing sample. The 
article finishes with a set of recommendations for faculty teaching FYS and similar courses. The researcher hopes to conduct this study with a larger group of participants in the future.

\section{LITERATURE REVIEW}

The central issue of this study, students' motivations for continuing to use CT in their work, has received little to no direct attention in past research. This emphasizes the potential for future research in this area. However, several major concepts will help readers to interpret findings of the present study. This review of the literature outlines major concepts and research in the study of motivation as connected with learning. It then focuses on two subtopics in the study of motivation: interest and motivation in traditional versus nontraditional students. It will then discuss transfer of learning and research on transfer of learning among students in higher education. Finally, the review will discuss CT in a general sense, as well as topics within the study of CT in higher education.

\section{Motivation and learning}

The field of educational psychology provides rich insights and concepts for understanding the motivations that support student learning. Psychologists have created numerous models for the motivations behind learning that provide insights into different aspects. Two major figures in the study of motivation and learning, Eccles and Wigfield, performed a major review of current theories and divided them into four categories: (a) theories focused on expectancy, (b) theories focused on reasons for engagement, (c) theories integrating expectancy and value constructs, and (d) theories integrating motivation and cognition $(2002,109)$. Working with theories from multiple categories allows readers to view their own questions through multiple lenses, providing different insights. Eccles's own research on modern expectancy-value theory (Eccles 1987) fits into the third category. Modern expectancy-value theory states that students consider four major concepts when considering how much effort to put into an academic task: (a) attainment value: "the personal importance of doing well on the task," (b) intrinsic value: enjoyment and interest related to the task, (c) utility value: perceived relevance to current and future goals, and (d) cost: "negative aspects of engaging in the task" (Eccles and Wigfield 2002, 119-20). All four of these concepts apply to the concepts and scenarios covered in this study. The first three are apparent in survey questions.

A concept called internalization, which has also been incorporated into educational psychology research for over 30 years, describes the process by which some students choose to adopt behaviors they have learned into their own personal processes (Deci and Ryan 1985). This can be used to describe situations in which study participants adopted CT skills into their personal processes for performing academic work. In the past 15 years, a great deal of research has been performed regarding first-year seminars' role as a high-impact practice: a practice that, when used in higher education, aids academic achievement, retention, and more (Kuh, O'Donnell, and Schneider 2017,9). The original report that identified first-year seminars as a high-impact practice examined higher-order thinking skills development among first-year students as an area of particular impact (NSSE 2006, 21). This study intends to add to the extensive body of research begun by that report.

\section{Motivation and interest}

Most teachers would agree that students engage more thoroughly with academic tasks when the subject or the skills involved pique their interest. Hidi's work on interest is frequently connected with 
work on motivation (see, for example, Eccles and Wigfield 2002, 114-15). Hidi's work explores two major types of interest. Situational interest refers to interest that an individual may feel toward a topic during one particular experience. Hidi notes that "Situational interest is environmentally triggered, involves an affective reaction and focused attention" $(2006,72)$. By contrast, students with an individual interest have an ongoing interest in a topic (Hidi 2006, 72-73). Hidi explains that "learners' individual interests energize and motivate their thoughts and actions in a very goal-directed way" (2006, 72). Hidi and Baird's earlier research indicates that situational interest can develop into individual interest (1986).

\section{Motivation in traditional and nontraditional students}

Another topic that feels familiar to experienced teachers in higher education is the differences in the motivations behind traditional and nontraditional students' learning. Justice and Dornan, whose work explores differences in adult learning based on age, define nontraditional students as being aged 25 or older $(2001,236)$. Justice and Dornan associate traditional students with an "assessment-focused approach," where they focus on scores they earn on tests and assignments and nontraditional students with a "deeper, comprehension-focused approach" (2001, 237). Rothes, Lemos, and Goncalves further this by discussing older students' focus on deep-learning strategies and mastery $(2017,7)$.

An experienced teacher in higher education may wonder whether the age-based divide between traditional and nontraditional students is too simplistic. Rothes and colleagues make the point that nontraditional students' burden of work- and family-related duties, in addition to schoolwork, can lead them to drop out of school (Rothes et al. 2017,7). This is certainly true of younger students who take on similar responsibilities.

\section{Andragogy}

Principles of andragogy — adult education — are highly relevant to this work. Malcolm Knowles, the pioneer of modern andragogy, writes that adult students, whether they are taking college courses or pursuing another learning goal, appreciate gathering information that will help them to solve problems and work toward "self-fulfillment" (Knowles 1978, 11). Knowles' work on andragogy also emphasizes the effectiveness of adult students learning from teachers who have been trained specifically in communicating with adult learners $(1978,18-19)$. Some principles that he describes include deemphasizing the instructor's authority and focusing on students' chosen interests (Knowles 1978, 1011); these principles are evident in teaching used in this first-year seminar program. Andragogy is also notably honest in terms of the attention it pays to adult students' needs outside the classroom: for example, family, work, and finances (see, for example, Giannoukos et al. 2015).

Throughout its history, andragogy has been continually modified, both in terms of variants on basic principles and in terms of tailoring to teaching specific subjects. In a well-cited example of a modification of basic principles, Akyildiz (2019) discusses adaptation of andragogical practices for teenage secondary school students, called heutagogy. Scholarly literature is also rich with articles on applications of andragogical principles in numerous fields of study in higher education; for example, entrepreneurship (Hägg and Kurczewska 2020), management (Forrest and Peterson 2006), science education (Remenick and Goralnik 2019), and nursing (Decelle 2016), among many others. 


\section{Transfer of learning}

Bransford, Brown, and Cocking are key scholars in the study of transfer of learning, which they define as "the ability to extend what has been learned in one context to new contexts" $(1999,51)$. Marton's definition of transfer of learning "refer[s] to the effect of learning to handle one task on our ability to handle another task" $(2015,72)$. The two definitions together help to define this broad concept which is visible throughout the many settings and challenges of higher education. This article incorporates both of those definitions and explores factors affecting transfer among a wide range of courses at an institution of higher education. It focuses on the factors motivating students and supporting that transfer.

Bransford, Brown, and Cocking's "four key concepts of transfer" $(1999,53)$ help readers to build a basic understanding of transfer of learning. The factors are:

1. Students must first learn a skill or knowledge in order to transfer it.

2. Embedding learning in too specific a context can decrease future transfer.

3. Transfer should be viewed as a process rather than a set of results or goals.

4. All new learning requires some transfer from previous learning.

These factors feel like common sense to educators, yet they highlight points at the core of transfer of learning.

\section{Critical thinking}

Critical thinking (CT) refers to the skills associated with "evaluating the accuracy, credibility, and worth of information and lines of reasoning" (Ormrod 2012, 421). CT is a core concept within many key parts of general education aimed at helping first-year undergraduate students build basic college skills, such as FYS programs. Ormrod (2012) identified four forms of CT: (a) verbal reasoning, creating and analyzing persuasive texts and techniques; (b) argument analysis, determining whether information provided supports or does not support an argument; (c) probabilistic reasoning, deciding whether a specific thing is or is not likely; and (d) hypothesis testing, creating a hypothesis and then designing and performing an experiment to test it $(2012,422)$.

\section{METHODOLOGY}

\section{Research sample and data sources}

This research occurred at the University of Colorado Denver, an urban public institution. In fall 2018 , the university reported enrollment of 11,010 undergraduate students, 2,328 of whom were firstyear students. Fifty-six percent of first-year students identified as either racial minorities or as international students (University of Colorado Denver Institutional Research 2019). Only a small number of students live on campus.

The researcher worked with the director of University of Colorado Denver's FYS program to connect with program faculty. Nine faculty members invited her to visit their courses (22 seats each) during the fall 2018 semester. The researcher invited interested students from these sections to work with her during the spring 2019 semester. A total of 152 students from the nine sections requested text or email invitations. The study was available from April 2 through May 13, 2019 (the end of final exams). Since participation had been low by early May, the director of the FYS also provided a link to the study as part of a weekly mailing to 500 students. Ultimately, 24 participated, yielding a response rate of 4.8 percent. 


\section{Data collection methods}

Each participant provided two types of data. The survey (appendix A) accessed through the invitation (see appendix C) asked them to (a) upload a copy of any paper written during their second semester in which they felt "proud" of the CT skills that they had used, and (b) complete a survey regarding motivating factors that have shaped their $\mathrm{CT}$ usage to the present. The message also contained an informed consent form and IRB contacts.

Instruments

The study evaluated each subject with two separate instruments: the Higher-Order Thinking Skills Rubric (appendix B) and a survey of motivating factors supporting CT usage.

\section{Rubric}

The study's rubric (appendix B) is adapted from the Association of American Colleges and Universities Critical Thinking and Information Literacy VALUE rubrics (AACU 2009; AACU 2013). The rubric evaluated CT (as well as IL) performance on the writing samples that students submitted. The rubric uses a single criterion to evaluate CT on a four-point scale: "Conclusions and related outcomes (consequences and implications).”

\section{Survey}

The survey (appendix A) is based on (a) the researcher's experience working with first-year undergraduates, both as an instructor and a librarian; (b) peer-reviewed literature exploring the factors that the researcher had identified by experience; and (c) the expertise of other faculty and the director of the FYS program.

The survey began with demographic items, a question on the student's major, and a question on the course for which the writing sample was created. The body of the survey contained 18 Likert-scale items, each rated on a four-point scale. Nine items related to motivational factors affecting use of CT skills.

Prior to the study, the researcher ran a pilot with three students. Students completed the survey in person. They narrated their choices as they worked, thus demonstrating interpretations of the survey items. Pilot responses were not included in the study.

\section{Data analysis}

Quantitative analysis

Quantitative analysis for this study began with descriptive statistics. For each survey item, the researcher calculated mean score and standard deviation. She then performed item analysis to help ensure that each item on the survey was effective. Preliminary results supported the use of all items.

\section{Qualitative analysis}

The qualitative portion of this work involved rubric analysis on the writing samples. Two collaborators assisted with this portion of the work. One removed personal identifiers that students had forgotten to remove from writing samples. The other helped calibrate rubric scoring of writing samples. The researcher and one collaborator then each evaluated all submitted writing samples using the rubric. They averaged each participant's scores to create an average CT rubric score. 


\section{Mixed methods}

The mixed methods analysis aimed to identify correlations between rubric scores and survey scores. After using the rubric to score each participant's writing sample, the researcher searched for (a) correlations between CT performance on the rubric and each of nine motivating factors in CT and (b) a correlation between an individual's ranking of motivating factors and the student's CT rubric score. The confidence level for correlations was set at 95 percent. $G^{*}$ Power statistical software showed that the study lacked sufficient responses to perform a regression analysis (requiring $n=34$ responses) but confirmed that correlations could be performed.

\section{Variables}

Since this study measured correlations between two sets of variables, there were no dependent or independent variables. All variables were considered equal.

Performance scores in terms of CT served as one set of variables. Performance was measured using the CT portions of the Higher-Order Thinking Skills Rubric. Nine motivating factors served as a second set of variables. Each motivating factor appears on one survey item relating to CT, as well as one survey item relating to IL (appendix B).

The nine motivating-factor-based items are as follows. The CT-related wording used is shown:

- My professors require critical thinking as part of assignments and/or give points specifically for critical thinking.

- I believe that strong critical thinking skills will help me to succeed in a future degree program (for example, a master's degree, law degree, medical degree, or Ph.D.).

- It is easy and/or natural for me to use critical thinking skills now.

- I believe that strong critical thinking skills will help me in my future career.

- My classmates' performance in class or study sessions inspires me to use my critical thinking skills.

- Other students (classmates, friends, peer tutors, etc.) have recommended that I use critical thinking skills on my assignments.

- I have learned to appreciate critical thinking through experiences that I have outside of school (such as in my social life, or while reading/watching media related to personal interests).

- I believe in thinking critically about important topics.

- I believe in thinking critically about what I read and hear.

Students read a definition of CT before beginning the survey, along with examples of behaviors related to these concepts. Text of the definitions and examples appear at the beginning of the survey (appendix A).

\section{Human subjects and confidentiality}

Data gathering was confidential rather than anonymous. Technology allowed the researcher to connect student writing samples with corresponding survey responses despite the lack of identifying information. Students used a secure online form to submit a Word or PDF copy of their chosen writing sample along with survey responses. The form and responses were accessible by only the researcher. In addition, the online database holding student writing samples was also accessible by only the researcher and the collaborator who checked for identifiers. 
All participants were eligible to receive a $\$ 5$ gift card to Starbucks. The researcher briefly downloaded the email addresses, copied them into the Starbucks site, sent the gift cards, and deleted the email addresses. Contact with the email addresses was as minimal as possible.

\section{LIMITATIONS AND DELIMITATIONS}

\section{Limitations}

The researcher hoped to perform regression analysis to fully validate survey items.

Unfortunately, due to receiving lower participation than required, this was not possible. Conducting the study with more participants and validating the survey are future goals.

While participants should be familiar with the concept of CT, they may not have a deep understanding. The definition provided in the survey should remind them of the concept. However, as they answered survey questions on CT, they may have done so with shallow understanding.

Study participants were all between ages 17 and 20, inclusive. While this is not surprising, given the nature of the course and characteristics of the student body, it limits some generalizability.

\section{Delimitation}

The choice to allow participants to submit any paper (writing sample) written in the second semester, as long as it employed CT and IL skills, was a delimitation. The researcher believed that this openness would make more students feel welcome to participate. It did, however, create less consistency in the writing samples.

\section{RESULTS}

A total of 24 students participated in this pilot study. Twenty-three submitted both survey responses and a writing sample. A brief technological problem allowed one additional participant to submit the survey without submitting a writing sample. That individual's survey responses are counted in calculations that do not incorporate performance scores.

\section{Sample population: descriptive statistics}

All study participants completed four questions on demographics. The following descriptive statistics are based on the 24 students who completed the survey, regardless of whether they also submitted the writing sample.

Age

The students $(\mathrm{n}=24)$ had a mean age of 18.8 years. Standard deviation for age was $\sigma=0.7$. Ages reported in the class ranged from 17 to 20 .

\section{Gender}

Students were asked to choose from four gender options on the survey: male, female, transgender, and other. The "other" option offered a free response. Of the 24 participants, 16 (67 percent) self-identified as female. Eight (33 percent) self-identified as male. None identified as transgender or "other." 


\section{First-generation status}

Students responded to the question, "Do you identify as a first-generation college student (first in your family to attend college)?” Response options were "yes" and "no." Of the 24 participants, 13 (54 percent) responded that "yes," they identify as first-generation college students. Eleven (46 percent) responded that "no," they do not identify as first-generation college students.

\section{College major}

Participants were asked, "What is your major?" This question was asked as a free response. Of the 24 participants, 21 ( 88 percent) listed a single major. Two participants ( 8 percent) identified as undeclared. One participant (4 percent) listed two majors. Participants identified a total of 16 majors (plus undeclared major status).

\section{Course for which writing sample was created}

Participants were asked to list the course for which they created their writing sample. Most provided the title (or a shortened title) for the course. Others provided a course number, primarily for courses that are popularly known by their number (e.g., English 2030). The researcher standardized names as much as possible: for example, knowing that Core Composition I and ENGL 1020 were the same course. However, in a few cases it was not possible to identify a specific course.

\section{Research question 1: descriptive statistics}

Research question (RQ) 1 asked, "What motivational factors are likely to contribute to first-year undergraduate students' willingness to apply critical thinking skills?” The question aims to find the most influential motivating factors for all participants. RQ 1 was supported by quantitative data gathered through the Likert-style items, as well as several free responses.

\section{Item analysis}

The quantitative data used in RQ 1 has a high internal consistency. Cronbach's $\alpha$ for all 18 Likert-style survey items was 0.83 . Cronbach's $\alpha$ for the nine Likert-style CT survey items was 0.74 , which indicates less consistency, but enough to support use.

\section{Critical thinking}

Table 1 shows selected statistics on participants' responses related to motivating factors and CT. Factors are presented on the table from highest to lowest in terms of the average scores (one to four points) that students assigned them. The section of the survey focusing on motivating factors for CT had a short introduction that read, "What are some reasons that you continue to use the critical thinking skills that you learned during your FYS course (and perhaps other courses) last semester?" followed by the nine Likert-style items on specific motivating factors. 
Table 1. Motivating factors related to critical thinking

\begin{tabular}{|l|l|l|}
\hline Motivating factor & Mean & $\begin{array}{l}\text { Standard } \\
\text { deviation } \\
\text { of scores }\end{array}$ \\
\hline I believe that strong critical thinking skills will help me in my future career. & 3.83 & 0.38 \\
\hline I believe in thinking critically about important topics. & 3.79 & 0.41 \\
\hline I believe in thinking critically about what I read and hear. & 3.75 & 0.44 \\
\hline $\begin{array}{l}\text { I believe that strong critical thinking skills will help me to succeed in a future degree } \\
\text { program (for example, a master's degree, law degree, medical degree, or Ph.D.). }\end{array}$ & 3.71 & 0.55 \\
\hline $\begin{array}{l}\text { I have learned to appreciate critical thinking through experiences that I have outside } \\
\text { of school (for example, in my social life, while writing or pursuing other creative } \\
\text { hobbies, or while reading/watching media related to personal interests). }\end{array}$ & 3.67 & 0.56 \\
\hline $\begin{array}{l}\text { My professors require critical thinking as part of assignments and/or give points } \\
\text { specifically for critical thinking. }\end{array}$ & 3.58 & 0.58 \\
\hline It is easy and/or natural for me to use critical thinking skills now. & 3.33 & 0.76 \\
\hline $\begin{array}{l}\text { My classmates' performance in class or study sessions inspires me to use my critical } \\
\text { thinking skills. }\end{array}$ & 2.83 & 0.96 \\
\hline
\end{tabular}

\section{Free response: critical thinking}

A free response item at the end of the CT section asked, "If something else inspires you to continue using your critical thinking skills, please describe it here." Only two of 24 participants (8 percent) provided a response to this question. Responses were, "I still feel like my critical thinking skills are developing as I go through college" and "I feel like I find personal confidence when I am confident in what I present in my classes."

\section{Research question 2: Descriptive statistics}

RQ2 explored the motivating factors most highly correlated with high performance on students' writing samples in CT. In effect, RQ 2 was intended to identify motivating factors that were most correlated with high levels of performance.

\section{Critical thinking performance and motivating factors for critical thinking}

Table 2 shows the correlations between each motivating factor for CT and CT performance on the writing sample, scored using the rubric. Since none of the p-values are less than 0.05 , none of the motivating factors proved to be correlated with CT performance on the writing sample. 
Table 2. Correlations between critical thinking performance on the writing sample and critical thinking motivating factors

\begin{tabular}{|c|c|c|}
\hline Motivating factor for critical thinking & $\begin{array}{l}\text { Pearson correlation with } \\
\text { critical thinking } \\
\text { performance on writing } \\
\text { sample }\end{array}$ & $\begin{array}{l}\text { Significance (two- } \\
\text { tailed) }\end{array}$ \\
\hline $\begin{array}{l}\text { My professors require critical thinking as part of assignments } \\
\text { and/or give points specifically for critical thinking. }\end{array}$ & .298 & .167 \\
\hline $\begin{array}{l}\text { I believe that strong critical thinking skills will help me to } \\
\text { succeed in a future degree program (for example, a master's } \\
\text { degree, law degree, medical degree, or Ph.D.). }\end{array}$ & -.090 & .682 \\
\hline $\begin{array}{l}\text { It is easy and/or natural for me to use critical thinking skills } \\
\text { now. }\end{array}$ & -.158 & .473 \\
\hline I believe in thinking critically about important topics. & -.084 & .703 \\
\hline $\begin{array}{l}\text { I believe that strong critical thinking skills will help me in my } \\
\text { future career. }\end{array}$ & .269 & .215 \\
\hline I believe in thinking critically about what I read and hear. & .014 & .948 \\
\hline $\begin{array}{l}\text { My classmates' performance in class or study sessions inspire } \\
\text { me to use my critical thinking skills. }\end{array}$ & .086 & .697 \\
\hline $\begin{array}{l}\text { Other students (classmates, friends, peer tutors, etc.) have } \\
\text { recommended that I use critical thinking skills on my } \\
\text { assignments. }\end{array}$ & .036 & .871 \\
\hline $\begin{array}{l}\text { I have learned to appreciate critical thinking through } \\
\text { experiences that I have outside of school (for example, in my } \\
\text { social life, while writing or pursuing other creative hobbies, } \\
\text { or while reading/watching media related to personal } \\
\text { interests). }\end{array}$ & .024 & .915 \\
\hline
\end{tabular}

\section{DISCUSSION}

\section{Research question 1}

RQ1 asked "What motivational factors are likely to contribute to first-year undergraduate students' willingness to apply critical thinking skills?” 


\section{Motivating factors: critical thinking}

Table 1 shows the order in which students rated motivating factors for continued use of CT skills, from most popular (highest score) to least popular (lowest score). Dividing the motivating factors into several tiers of popularity helps to connect themes in the factors with educational psychology concepts.

Table 3.

\begin{tabular}{|c|c|c|}
\hline $\begin{array}{l}\text { Other students (classmates, friends, peer tutors, etc.) have recommended } \\
\text { that I use critical thinking skills on my assignments. }\end{array}$ & 2.54 & 0.98 \\
\hline $\begin{array}{l}\text { Note: Scores were presented to students as follows: (a) "very true for me" = } \\
\text { for me" = } 3 \text { points; (c) "somewhat untrue for me" = } 2 \text { points; and (d) "Not } \\
\text { Note. Mean scores and standard deviations have been rounded to two decin } \\
\text { differences in scores apparent. }\end{array}$ & 11 & $\begin{array}{l}\text { mewh } \\
=1 \mathrm{pc} \\
\text { e small }\end{array}$ \\
\hline
\end{tabular}

\section{Top-tier responses}

Thoughts of future careers and degree programs topped the list of motivating factors related to CT. In fact, using CT skills with thoughts of a future career in mind received the highest mean Likert score (3.83) of all items on the survey.

These future-oriented motivating factors may align well with Salomon and Perkins's concept of forward-reaching transfer. When students employ forward-reaching transfer, they purposefully collect and abstract information for later use (Salomon and Perkins 1989, 113). Students who use forwardreaching transfer are aware that what they are currently learning will likely help them to achieve future goals.

Next, students highlighted "I believe in thinking critically about important topics" (3.79) and "I believe in thinking critically about what I read and hear" (3.75). These motivating factors relate to Hidi's concepts of individual interest and situational interest, respectively $(2006,72)$. It is helpful as an instructor to know that topics of interest, whether situational or individual, do support students' continued use of CT.

\section{Bottom-tier responses}

The eighth- and ninth-place factors were, "My classmates' performance in class or study sessions inspires me to use my critical thinking skills" and "Other students (classmates, friends, peer tutors, etc.) have recommended that I use critical thinking skills on my assignments," in that order. There was a noticeable gap in scores between the seventh item and the bottom two (eighth and nineth places, respectively).

As an instructor, the researcher observes impressive displays of CT among students and now wonders whether students (a) feel intimidated by these displays, (b) fail to identify them as being displays of critical thought, or (c) something else. Students often excel at coaching each other on 
improving the mechanics and more surface-level content of their assignments but do not comment on deeper levels of reasoning in their classmates' work.

\section{Middle-tier responses}

Motivational factors that ended up in the middle range of the list for CT scored reasonably high, suggesting influence on students' decision-making processes. The fifth-most-popular factor on the list was "I have learned to appreciate critical thinking through experiences that I have outside of school (for example, in my social life, while writing or pursuing other creative hobbies, or while reading/watching media related to personal interests).” This factor scored 3.67, which was still relatively high. This item aligns with Bransford, Brown, and Cocking's definition of far transfer. They defined far transfer as the ability to take skills learned in school and apply them in a "non-school setting" (1999, 53).

Instructors requiring (and giving credit for) CT during assignments landed in sixth place. Perhaps students see this item as a given and thus do not harbor strong positive or negative feelings about it.

The fact that "It is easy and/or natural for me to apply critical thinking skills now" was in seventh place on the list of motivating factors for critical thinking makes sense given Salomon and Perkins's discussions of high- and low-road skills $(1989,113)$. High-road skills such as CT require conscious abstraction and practice to develop. Low-road skills, by contrast, develop naturally through use. At this point in their educational careers and their intellectual development, students may not feel that CT skills come naturally or easily to them.

\section{Research question 2}

RQ 2 asked, "Do certain motivational factors have a strong relationship with students' critical thinking performance on a paper that they have written for a course of their choice one semester after initially learning the skills?” The objective in asking this question was to identify factors that motivated the students who gave the strongest performances on the writing sample in terms of their usage of critical thinking and information literacy skills. The researcher's intent was to use those findings as part of future communications with students regarding the importance of CT skills.

Interestingly, there were no significant correlations between any of the nine motivating factors for continued CT usage and CT performance on the writing sample. After thinking through both statistical and classroom implications, the researcher believes that this will be a positive factor in future teaching.

\section{CONCLUSIONS AND RECOMMENDATIONS}

Findings of this study suggest a number of recommendations for the higher education classroom. These may be applied in FYS courses, and also extended to some degree to other courses in higher education.

Students with all current levels of applied CT performance respond similarly to motivating factors. This suggests that faculty may incorporate the motivating factors into assignments without worrying about tailoring them toward higher or lower performers.

Encouraging students to work with topics of interest motivates students to use their CT (and

IL) skills. One meaningful option that applies to many first-year seminars and similar undergraduate 
courses is exploration of careers and other future goals. Talking about use of CT in professional settings interests and engages students.

Another implication from the study is that students may need to be taught how to critique others' use of CT skills, as well as how to learn from others' examples of CT. Existing models for peer critique, such as those used to critique peers' writing, may provide useful models.

The researcher looks forward to implementing these findings with larger groups of first-year students. She also intends to explore trends uncovered through this project in other undergraduate academic scenarios. In the meantime, she will apply preliminary findings to her own teaching.

Karen Sobel is an associate professor and teaching and learning librarian at the University of Colorado Denver (USA).

\section{REFERENCES}

Akyildiz, Seçil Tümen. 2019. “Do 21st Century Teachers Know about Heutagogy or Do They Still Adhere to Traditional Pedagogy and Andragogy?" International Journal of Progressive Education 15, no. 6: 151-69.

Association of American Colleges and Universities (AACU). "Critical Thinking VALUE Rubric." 2009. https://www.aacu.org/value/rubrics/critical-thinking.

Association of American Colleges and Universities (AACU). "Information Literacy VALUE Rubric." 2013. https://www.aacu.org/value/rubrics/information-literacy.

Bransford, John, Ann L. Brown, and Rodney R. Cocking, (Eds.). 1999. How People Learn: Brain, Mind, Experience, and School. Washington, DC: National Academy Press.

Decelle, Gina. 2016. "Andragogy: A Fundamental Principle of Online Education for Nursing." Journal of Best Practices in Health Professions Diversity: Education, Research and Policy 9, no. 2: 1263-73.

Deci, Edward L., and Richard M. Ryan. Intrinsic Motivation and Self-Determination in Human Behavior. New York: Plenum, 1985.

Eccles, Jacquelynne S. 1987. "Gender Roles and Women's Achievement-Related Decisions." Psychology of Women Quarterly 11: 135-72.

Eccles, Jacquelynne S., and Alan Wigfield. 2002. "Motivational Beliefs, Values, and Goals." Annual Review of Psychology 53, no. 1:109-32.

Forrest, Stephen Paul, and Tim O. Peterson. 2006. "It's Called Andragogy." Academy of Management Learning and Education 5, no. 1:113-22.

Giannoukos, Georgios, Georgios Besas, Christos Galiropoulos, and Vasilios Hioctour. 2015. "The Andragogy, the Social Change and the Transformative Learning Educational Approaches in Adult Education." Journal of Education and Practice 6, no. 10: 46-50.

Hägg, Gustav, and Agnieszka Kurczewska. 2020. "Guiding the Student Entrepreneur - Considering the Emergent Adult within the Pedagogy-Andragogy Continuum in Entrepreneurship Education." Education + Training 62, no. 7/8: 759-77. https://doi.org/10.1108/ET-03-2020-0069.

Hidi, Suzanne. 2006. "Interest: A Unique Motivational Variable." Educational Research Review 1, no. 2: 69-82.

Hidi, Suzanne, and William Baird. 1986. "Interestingness—A Neglected Variable in Discourse Processing." Cognitive Science 10: 179-94.

Justice, Elaine M., and Teresa M. Dornan. 2001. "Metacognitive Differences between Traditional-Age and Nontraditional-Age College Students." Adult Education Quarterly 51, no. 3: 236-49.

Knowles, Malcolm S. 1978. "Andragogy: Adult Learning Theory in Perspective." Community College Review 5, no. 3: 9-20. https://doi.org/10.1177/009155217800500302.

Kuh, George, Ken O'Donnell, and Carol Geary Schneider. 2017. "HIPs at Ten." Change: The Magazine of Higher Learning 49, no. 5: 8-16.

Marton, Ference. 2015. Necessary Conditions of Learning. $1^{\text {st }}$ ed. New York: Routledge.

National Survey of Student Engagement (NSSE). Engaged Learning: Fostering Success for All Students. Annual Report 2006. National Survey of Student Engagement. https://eric.ed.gov/?id=ED512619. 
Ormrod, Jeanne Ellis. 2012. Human Learning. 6th ed. Boston: Pearson.

Remenick, Lauren, and Lissy Goralnik. 2019. "Applying Andragogy to an Outdoor Science Education Event." The Journal of Continuing Higher Education 67, no. 1: 24-36. https://doi.org/10.1080/07377363.2019.1629804.

Rothes, Ana, Marina S. Lemos, and Teresa Gonçalves. 2017. "Motivational Profiles of Adult Learners." Adult Education Quarterly 67, no. 1:3-29.

Salomon, Gavriel, and David N. Perkins. 1989. "Rocky Roads to Transfer: Rethinking Mechanisms of a Neglected Phenomenon." Educational Psychologist 24, no. 2: 113-42.

University of Colorado Denver Institutional Research and Effectiveness. 2019. [Data on University of Colorado Denver First-Year Students Enrolled in Fall 2018 Organized Using Tableau Public Software, September 3 2019]. Denver Campus Fall 2018-End of Term. Accessed June 14, 2021.

https://www1.ucdenver.edu/offices/institutional-research-and-effectiveness/dataanalysis/studentdata/enrollment-and-demographics. 


\section{APPENDIX A: SURVEY USED IN THIS STUDY}

Dear Student,

Please upload a paper that you have written for any course this semester. In addition, please make sure that it is a paper where you were required to refer to outside sources (such as articles, books, websites, etc.). Choose one where you are proud of the work you have done with (a) critical thinking and (b) information literacy.

Definitions:

- Critical thinking: "evaluating the accuracy, credibility, and worth of information and lines of reasoning” (Ormrod 2012, 421). In other words, have you analyzed others' reasoning and arguments, or created strong reasoning or arguments of your own?

- Some actions that you might have taken related to critical thinking are

- spending time analyzing or researching whether something you have heard could be true

- looking for alternative opinions on a subject

- debating different sides of a topic with someone else or choosing to listen to a debate

- thinking about the assumptions behind what a person or group has said or written

- Information literacy: "recognizing when information is needed and have the ability to locate, evaluate, and use effectively the needed information" (American Library Association 1989).

- Some actions that you might have taken related to information literacy are

- thinking about whether a website you visited is reliable

- thinking about what facts, statistics, or ideas would best support an idea that you have

- visiting a library or a library's website

- asking a librarian, professor, or friend for advice on your research

Note that if you have questions or technical difficulties, you may contact me, Karen Sobel, at karen.sobel@ucdenver.edu.

Please remove your name from your paper before submitting. $\{\{$ UPLOAD BOX $\}\}$

Title of your paper: [free response] (Note: This helps ensure that I can connect your paper and your survey responses.)

\section{Demographics}

1. What is your age? [Enter years.]

2. What is your gender? [female, male, transgender, other: [free response]]

3. What is your major? [menu]

4. What department did you write this paper for? [menu]

5. Do you identify as a first-generation college student (first in your family to attend college)? [yes, no] 


\section{Questions}

What are some reasons that you continue to use the critical thinking skills that you learned during your first-year seminar course (and perhaps other courses) last semester?

- My professors require critical thinking as part of assignments and/or give points specifically for critical thinking.

4 (very true for me) 321 (not at all true for me)

- I believe that strong critical thinking skills will help me to succeed in a future degree program (for example, a master's degree, law degree, medical degree, or Ph.D.).

4 (very true for me) $32 \quad 1$ (not at all true for me)

- It is easy and/or natural for me to use critical thinking skills now.

4 (very true for me) 321 (not at all true for me)

- I believe in thinking critically about important topics.

4 (very true for me) 321 (not at all true for me)

- I believe that strong critical thinking skills will help me in my future career.

4 (very true for me) 3221 (not at all true for me)

- I believe in thinking critically about what I read and hear.

4 (very true for me) 321 (not at all true for me)

- My classmates' performance in class or study sessions inspires me to use my critical thinking skills.

4 (very true for me) 321 (not at all true for me)

- Other students (classmates, friends, peer tutors, etc.) have recommended that I use critical thinking skills on my assignments.

4 (very true for me) 321 (not at all true for me)

- I have learned to appreciate critical thinking through experiences that I have outside of school (such as in my social life, or while reading/watching media related to personal interests). 4 (very true for me) 321 (not at all true for me)

- Other: [Short free response]

What are some reasons that you continue to use the information literacy skills that you learned during your first-year seminar course (and perhaps other courses) last semester? 
4 (very true for me) 321 (not at all true for me)

- My professors require information literacy as part of assignments and/or give points specifically for information literacy (such as finding articles in journals or going to the library).

4 (very true for me) 321 (not at all true for me)

- I believe that strong information literacy skills will help me to succeed in a future degree program (for example, a master's degree, law degree, medical degree, or Ph.D.). 4 (very true for me) 321 (not at all true for me)

- It is easy and/or natural for me to use information literacy skills now.

4 (very true for me) 321 (not at all true for me)

- I believe in searching for reliable information sources to learn about important topics. 4 (very true for me) 321 (not at all true for me)

- I believe that strong information literacy skills will help me in my future career. 4 (very true for me) 321 (not at all true for me)

- I believe in researching the reality behind what I read and hear. 4 (very true for me) 321 (not at all true for me)

- My classmates' performance in class or study sessions inspires me to use my information literacy skills.

4 (very true for me) 321 (not at all true for me)

- Other students (classmates, friends, peer tutors, etc.) have recommended that I use information literacy skills on my assignments.

4 (very true for me) 321 (not at all true for me)

- I have learned to appreciate information literacy through experiences that I have outside of school (such as in my social life, or while reading/watching media related to personal interests). 4 (very true for me) 321 (not at all true for me)

- Other: [Short free response]

Is there anything else that you'd like to tell me? [short free response] 


\section{APPENDIX B: RUBRIC USED IN THIS STUDY}

The complete rubric is referred to as the "Higher-Order Thinking Rubric." It consists of two sections: information literacy and critical thinking.

\section{Information literacy section}

The rubric item and rating levels used for assessing the information literacy content of students' papers were as follows:

Criterion: "Evaluate information and its sources critically."

\begin{tabular}{|l|l|l|l|}
\hline 4 points ("capstone") & 3 points ("milestone") & 2 points ("milestone") & 1 point ("benchmark") \\
\hline $\begin{array}{l}\text { Chooses a variety of information } \\
\text { sources appropriate to the scope } \\
\text { and discipline of the research } \\
\text { question. Selects sources after } \\
\text { considering the importance (to } \\
\text { the researched topic) of the } \\
\text { multiple criteria used (such as } \\
\text { relevance to the research question, } \\
\text { currency, authority, audience, and } \\
\text { bias or point of view). }\end{array}$ & $\begin{array}{l}\text { Chooses a variety of } \\
\text { information sources } \\
\text { appropriate to the scope } \\
\text { and discipline of the } \\
\text { research question. Selects } \\
\text { sources using multiple } \\
\text { criteria (such as relevance } \\
\text { to the research question, } \\
\text { currency, and authority). }\end{array}$ & $\begin{array}{l}\text { Chooses a variety of } \\
\text { information sources. } \\
\text { Selects sources using } \\
\text { basic criteria (such as } \\
\text { relevance to the } \\
\text { research question } \\
\text { and currency). }\end{array}$ & $\begin{array}{l}\text { Chooses a few } \\
\text { information } \\
\text { sources. Selects } \\
\text { sources using } \\
\text { limited criteria } \\
\text { (such as relevance } \\
\text { to the research } \\
\text { question). }\end{array}$ \\
\hline
\end{tabular}

(Modified from AACU 2013)

\section{Critical thinking section}

The rubric item and rating levels used for assessing the critical thinking content of students' papers were as follows:

Criterion: "Conclusions and related outcomes (implications and consequences)"

\begin{tabular}{|c|c|c|c|}
\hline 4 points ("capstone") & 3 points ("milestone") & 2 points ("milestone") & 1 point ("benchmark") \\
\hline $\begin{array}{l}\text { Conclusions and related } \\
\text { outcomes (consequences } \\
\text { and implications) are } \\
\text { logical and reflect student's } \\
\text { informed evaluation and } \\
\text { ability to place evidence } \\
\text { and perspectives discussed } \\
\text { in priority order. }\end{array}$ & $\begin{array}{l}\text { Conclusion is logically } \\
\text { tied to a range of } \\
\text { information, including } \\
\text { opposing viewpoints; } \\
\text { related outcomes } \\
\text { (consequences and } \\
\text { implications) are } \\
\text { identified clearly. }\end{array}$ & $\begin{array}{l}\text { Conclusion is logically } \\
\text { tied to information } \\
\text { (because information is } \\
\text { chosen to fit the desired } \\
\text { conclusion); some related } \\
\text { outcomes (consequences } \\
\text { and implications) are } \\
\text { identified clearly. }\end{array}$ & $\begin{array}{l}\text { Conclusion is } \\
\text { inconsistently tied to } \\
\text { some of the } \\
\text { information discussed; } \\
\text { related outcomes } \\
\text { (consequences and } \\
\text { implications) are } \\
\text { oversimplified. }\end{array}$ \\
\hline
\end{tabular}

(Modified from AACU 2009) 
APPENDIX C: STUDENT CONTACT LETTER

Study title: "Transfer of Learning of Higher-Order Thinking Skills"

PI: Karen Sobel

Protocol number: 18-1879

Version date: 10 March 2018

Dear student,

Hello! Thank you for considering participating in my research project, "Transfer of Learning of Higher-Order Thinking Skills." I am investigating how students decide how and when to use critical thinking and information literacy skills throughout the first year of their undergraduate degree.

The Colorado Multiple Institutional Review Board (COMIRB) oversees the ethics of this study. I provide details on the terms of the study, approved by COMIRB, below. If you choose to submit (a) a paper and (b) survey responses, you are agreeing to the terms of the study. If you are not comfortable with the terms of the study (listed below), please do not submit a paper or complete the survey.

\section{Terms of the Study}

Participation: Your participation is optional. It has no impact on your grade for any course. None of your professors will receive information regarding participation.

Anonymity: I [Karen Sobel] will retain a password-protected list of the email addresses of individuals who have participated until I have awarded each of the gift card drawing recipients. The list will only be accessible by me.

Risks: There are no known risks, especially since your participation is anonymous.

Benefits: You will be entered in a drawing for one of four \$25 Amazon gift cards. Winners will receive notification via email and will receive the gift cards by the end of spring semester 2019.

Concerns: If you have questions or concerns, you may contact me, Karen Sobel (karen.sobel@ucdenver.edu; [telephone number redacted]). You can also contact the Colorado Multiple Institutional Review Board (COMIRB), which oversees the ethics of the study. Their contact is comirb@ucdenver.edu or [telephone number redacted].

Confidentiality: Papers will be kept in a password-protected, cloud-based database accessible only to me. Survey responses will be kept on a password-protected online spreadsheet.

Again, your participation in this study is completely voluntary.

Thank you for considering participation!

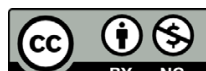

Copyright for the content of articles published in Teaching \& Learning Inquiry resides with the authors, and copyright for the publication layout resides with the journal. These copyright holders have agreed that this article should be available on open access under a Creative Commons Attribution License 4.0 International (https://creativecommons.org/licenses/by-nc/4.0/). The only constraint on reproduction and distribution, and the only role for copyright in this domain, should be to give authors control over the integrity of their work and the right to be properly acknowledged and cited, and to cite Teaching \& Learning Inquiry as the original place of publication. Readers are free to share these materials - as long as appropriate credit is given, a link to the license is provided, and any changes are indicated. 
